\title{
IBADIZMAS KAIP PAGRINDAS OMANIEČIO MĄSTYTOJO IR MOKYTOJO ABU MUSLIM AL-BAHLANI POEZIJOS ANALIZEI
}

\author{
Ibadism as a Cornerstone in the Analysis of the Poetry \\ of Omani Educator and Thinker Abu Muslim Al-Bahlani
}

\section{SUMMARY}

The article studies the phenomenon of Ibadism as an Islamic movement and state ideology in the Sultanate of Oman. As a theological branch, Ibadism has significantly influenced political development and changed the history of this country. It has contributed towards Oman's unique path in the global world. Nowadays, non-interference and mediation make the basis of Omani policy. The author focuses on the theoretical pillars of Ibadism and its political background as well as the intellectual heritage of the country. The author uses the example of the activity and life of Abu Muslim al-Bahlani, the outstanding Omani poet, public figure and educator of the end of the XIX and the beginning of the XX century. Abu Muslim al-Bahlani's legacy and life became a symbol of the implementation of Ibadism. His impact was recognized by UNESCO in 2019. Following interdisciplinary approaches, the author concludes that the principles of Ibadism are reflected in his poetry and have been examined in all spheres of everyday life, including art and culture, a fusion of religion and civil consciousness.

\section{SANTRAUKA}

Straipsnyje nagrinėjamas ibadizmo - Omano sultonato islamo judejjimo, tapusio valstybės ideologija - fenomenas. Kaip teologijos šaka ibadizmas darè didelę i̇taką politinei šalies raidai. Jis pakeitè šios šalies istoriją, suformavo unikalų jos kelią globaliame pasaulyje. Šiandien omaniečių politikos pagrindą sudaro nesikišimo ir tarpininkavimo strategija. Remiantis 19 a. pabaigos ir 20 a. pradžios iškilaus omaniečių poeto, visuomenės veikejjo ir švietėjo Abu Muslim al-Bahlani darbų ir gyvenimo pavyzdžiu, straipsnyje analizuojami teoriniai ibadizmo pamatai, šios islamo šakos politinis pagrindas bei intelektinis paveldas. Abu 
Muslim al-Bahlani gyvenimas ir veikla tapo ibadizmo simboliu. Šio visuomenės veikèjo nuopelnus Omano raidai 2019 m. pripažino UNESCO. Vadovaudamasi tarpdiscipliniškumo prieigomis, straipsnio autore daro išvadą, kad ibadizmo principai atsispindi Abu Muslim al-Bahlani poezijoje, jų aptinkama visose kasdienio gyvenimo srityse: mene ir kultūroje, religijoje ir pilietinèje sąmonẻje.

\section{INTRODUCTION}

On the 14th of November 2019 at the headquarters in Paris on the $40^{\text {th }}$ General Conference, UNESCO announced the inclusion of Omani poet, social activist and educator Nasser bin Salem bin Udeim al-Rawahi, well-known as Abu Muslim al-Bahlani, among the world's most influential figures. His impact was recognized as a cultural and historical heritage for humanity (Oman Observer 2019). The announcement was made on the centenary of the death of Abu Muslim al-Bahlani, who passed away in 1920.

The poet was born in Oman, a unique country due to its geographical location, which is in the far west of the Arab world and separated from the rest of the Arab states by the impassable desert al-Rub al-Khali (The Empty Quarter). The culture of Oman became a point of synergy point between the customs and characters of the original Arabian tribes and the traditions of neighbouring India and the dominions of Oman in East Africa.

Surely, the certain position of the state was reflected even in the political administration of the Sultanate of Oman as the state was founded after centuries-old civil conflicts and the final elimination of the Imamate (Islamic religious ruling system). Thereafter, this encouraged the introduction of the Islamic movement of Ibadism. Being a theological movement, Ibadism played a key role in the history of the country and became imprinted in its intellectual heritage. Nowadays Ibadism is not widely spread outside Oman, though it continues to maintain a significant background in the country's development and national identity.

Until recent days, Oman was considered the hermit of the Middle East. Its political and cultural position of peacebuilding and non-interference in international conflicts, its certain closedness to the rest of the world, has been the same since the golden century of the Arab Caliphate in the Umayyad period (661-750, with a certain exception in the rule of Cordova Caliphate) and Abbasid times (750-1258), when Omani tribes had conflicts with Arab califs and remained separated from the scientific and literary caliphate life (the so-called "Golden Age" of Arabic science and literature). The isolation policy of Oman continued even until the middle of the XX century in the time of Sultan Said bin Taimur's governance (1932-1970), when the state limited cooperation with the rest of the world, and citizens were even prohibited from going abroad.

Notwithstanding that international isolation resulted in a certain way of development of Omani culture, including in philosophy and literature, it also led to the unknown "pearls" of Omani poetry and cultural figures outside Oman. Nevertheless, due to the later opening-up and liberalizing policy of Sultan Qaboos bin 
Said, who governed from 1970 until his death in 2020, international recognition of Oman started to grow. Over the last decades UNESCO has included four Omanis in the list of global influential figures besides al-Bahlani. Thus, in 2006 UNESCO included al-Khalil ibn Ahmad al-Farahidi (718-791), a linguist, who developed the system of vowels of the Arabic script, the system of versification (Arabic prosody) (al-arud), and was the initiator of the first dictionary of the Arabic language Al-Ain (source). A native of Oman, he moved to Basra, Iraq, to the famous linguistic school. In 2013 UNESCO also included Rashid bin Umeira, a doctor and a pharmacist (lived at the end of the 15th, the beginning of the 16th centuries). In 2015 it included Sheikh Nur adDin al-Salmi (1868-1914), who was an encyclopedist, historian and social reformer. Finally, physicist and physician, medical encyclopedist Abu Muhammad al-Azdi, known as Ibn al-Dahabi (died 1033). Al-Bahlani (1860-1920) became the fifth and latest Omani to be inscribed on this honorary list (Oman Observer, 2019).

The activity of al-Bahlani attracts special attention due to the following reasons. Firstly, he made a big impact on the development of the ideology of Ibadism, though outside Oman his philosophical and civil roles have not been sufficiently studied. In some researches, he is mentioned as a founder of the first Omani (Zanzibar) newspaper (Al-Shahri 2005:24). In this article, the research is based mostly on Arabic sources from works by historians and linguists from Oman and the United Arab Emirates, and researches into Ibadism in English.

Secondly, in his works al-Bahlani reflects the practice of the religious move- ment of Ibadism and its coherence with the social and political positions of civil society. That allows us to explain the deep meaning of all social and political transformations from tribal relations to present-day society in the Arabian Peninsula. Moreover, his works explained the history of the mutual development of Zanzibar (Omani territory until 1961) and Oman, and their complex co-existence until the middle of the XXth century; this had also significantly influenced their special cultural way of development. The joint development of the territories also brought about the unification of the Omani nation and the formation of the national identity that exists nowadays (Nizwa, 1996).

Finally, Al-Bahlani's works encouraged the development of a national literature on a new level, bringing with it value and aesthetics. He managed to unify neatly special methods of Arabic language and Quranic style, express his joint religious and civil position, and introduce educational and political activity. Certainly, the explanations in his works help to understand the region and Oman as a state, its history and culture, its political administration and economic development, diplomacy and the role of religion in the life of Omani society. As the region plays a bigger role in global affairs and attracts more attention, it is important to research its ideology and civil beliefs.

The research question of the article is to define the political content of Ibadism and its features in the works of al-Bahlani, based on the analysis of his poetry, and to evaluate how far it influenced political stability and civil society building in Oman. 


\section{OMANI IBADISM IN ITS POLITICAL AND SOCIAL CONTEXT}

From a historical perspective, Ibadism is one of the ideological minority movements in Islam and comes from Kharijite movements. The Kharijites (Arabic meaning is "those who left") are known as people who, after the death of Prophet Muhammad (died in 632) and within the conflict of leadership that resulted, opposed the fourth ruler of the Islamic Caliphate, Ali ibn Abi Talib. Ali ibn Abi Talib became the founder of the Umayyad dynasty of Muawiyah (Ignatenko 2000). When the Kharijites left the Caliphate, they divided into many religious movements. One of them, Ibadism, appeared in Iraq, in Basra. It was named after the political leader Abdullah ibn Ibad at-Tamimi ${ }^{1}$ (died in 708) and later, the ideology spread into Oman via Omanis in Eastern Africa, certain parts of Libya (Nafusa Mountains, Zunga) and in the south of Algeria (Warglya, Mizab). Ibadism is compared by researchers to an egg, with the egg laid in Mecca, while the bird was bred in the nest in Basra, and then flew on to Oman.

Further, Ibadites tried to establish the Imamate on the eve of the Umayyad Caliphate; however, after the Battle of Nahrawan in 658 they failed. Later, in 757 the first Imamate of Oman of Imam alJalyandi bin Masud was defeated by the Abbasids; after that the Imamate existed for a long time under the rule of the dynasties of Al Nabhany (1154-1624) and Yaruba (1624-1749). Other attempts to promote Ibadism were the movement of Imam Azzan bin Qais (died in 1871) of the $\mathrm{Al} \mathrm{Bu}$ Said dynasty that rules today, and the so-called revolutionary Jebel Akhdar War² of 1957 (The Oman War), led by Imam Ghalib Alhinai (1912-2009), elected Imam in 1954 (Wilkinson 1986).

In time Ibadism was absorbed by society as it created effective tools for the unification of the nation, the issue being perpetually the focus of internal conflicts, together with Portuguese expansion (1506-1650) and the Wahhabis. Finally, Ibadism became a crucial factor in uniting the nation, the very separated life of the state, and defined its intellectual and artistic development.

Meanwhile, only in the XX century did Ibadism fully enter Oman's public administration. The question is: why did such active resistance to secular authorities - which did not impede the colonial claims of the West - appear precisely in the Ibadite state? Followed by the question: why did only the increasing military budget of Sultan Qaboos, the contemporary political leader, put an end to this resistance? (Senchenko 2020)

To answer these questions, we will explain the basics of Ibadism through fundamental studies by Arab scholars. Ibadism, like other Kharijites, combines the denial of the divine attributes of the description of God and belief in the creation of the Quran (Atik \& Shaaban 2015: 23). But Ibadism emphasizes its moderation among other minority trends in Islam. Ibadism denies any acts of aggression and militancy since extreme acts towards an enemy would be considered inhumane (Al-Rawas 2000: 81). The central focus of their ideology is to strength- 
en the position of society and deny aspects that would make Muslims personally and politically weak.

The Ibadites are strict, first of all towards themselves - they call an unbeliever one who commits a great sin, while the people of the Sunnah and the Communities (Shiites) call such a person only a disobedient or ungodly person. One who died in this state, according to the beliefs of the people of the Sunnah, may be forgiven by the grace of the Almighty, or God will punish him justly to cleanse him of sins, and then lead him to Paradise. But the Ibadites believe that the sinner will forever remain in Hell, and this opinion fully coincides with the statements of the rest of the Kharijites (Hoffman 2015: 301). That implies that the rulers have more responsibility in their governance.

In the practical delivery of the postulates of Ibadism - suluk (from Arabic behaviour) - is the way of worshipping God, undoubtedly associated with zuhd (from Arabic - asceticism) as a way of giving less importance to this life, but it is also a set of ideas aimed at transforming society to enable sustainable development in all spheres of life. These ideas maintain that the state has to be governed by a religious leader. However, despite the other Islamic approaches, the main difference in Ibadism is that it allows citizens to rebel against unjust rulers and government. It supports the promotion of democracy, choice, and power of society.

The most important political description of Ibadism is as a system focused on transforming society and creating a state governed by a religious leader. Meanwhile, the leader is appointed and has the functions of an authorized person, rather than a ruler with unlimited power (Atik \& Shaaban 2015: 27). A leader has to be elected by people, does not inherit the position, because the Prophet Muhammad did not name his successor, as it is known, and did not transfer control of the Muslims to someone's hands. Moreover, Ibadites recognize the permissibility of rebellion against unjust rulers (Atik and Shaaban 2015: 40) and deny that the leader must necessarily come from the Quraish tribe as the Prophet Muhammad (Atik and Shaaban 2015: 38). The Ibadites consider that the imam of the whole community can be any Muslim, referring to the hadith of the Prophet Muhammad: "If the [Ethiopian slave] ... is placed as a ruler over you and establishes the Divine Scripture and my Sunna (Rules) between you, then listen to him and obey him" (Ignatenko 2009: 53).

Due to the reasons explained above, Arab scholars describe Ibadism as the most democratic, the most revolutionary, and the most socialist (Husain 2020). The vast attention to public life and public justice undoubtedly makes it attractive to the majority of its followers who dream to establish these ideas and develop an active public position in them regarding the observance of Sharia social norms in matters of equality and justice. The social, economic and religious conditions contributed to the appearance on Omani soil during al-Bahlani's time of the most artistic samples of literature, which are an alloy of art, 
religion, and politics - civil and religious poetry. The brightest representative of this was Abu Muslim al-Bahlani himself, consistently reflecting, as will be shown below, the postulates of Ibadism in his life and work.

\section{HISTORICAL AND RELIGION DIMENSIONS IN AL-BAHLANI'S OEUVRE}

To understand why Ibadism is significantly reflected in the life and activity of al-Bahlani, we will study his education and professional development. Nasser bin Salem bin Udeim was born in 1860 (according to some sources in 1857) in the Bani al-Rawah Valley, socalled Inland Oman, 150 kilometres from the capital of Muscat, deep into the Arabian Peninsula. Near his hometown, there is an ancient city of Bahla that was the capital of the Al Nabhani ruling dynasty from the 12th to the 17th centuries. Therefore, the poet is named after his place of origin as al-Rawahi and al-Bahlani, as well as simply al-Omani, and another name - Abu Muslim (from Arabic - the father of Muslim) - al-Bahlani, probably received traditionally after the birth of his son. According to tradition, in his youth, the poet signed as bin Udeim, which means the son, grandson, descendant of Udeim.

His father Salem bin Udeim al-Bahlani was a judge, which is considered a most influential and prestigious position in the Arab world. He worked in Nizwa city, which was the center of Islamic scholarship in Oman. Moreover, it was a time when the region was ruled by imam Azzan bin Qais Al Bu Saidi (in 18681871 ), and it was a period when the Imamate - the religious rule - was established through the most of the territory.
There was no civic education, no public schools in the country, with the only education a person could have being a religious one. Therefore, al-Bahlani received his education by studying the Quran and Islamic Law (al-Figh). It was essential, then, to receive education from famous and well-recognized Islamic scholars. Al-Bahlani's teachers, well known in the Islamic world, were scholars such as Salih bin Ali al-Harthi, Rashid bin Seif bin Said al-Lyamki, Majid bin Khamis al-Ibri, and others (Babaahmed 2019). Traditionally, students who wanted to study with the best scholars had to move from one city to another if their professor decided to move to another city. That is why even the meaning of Arabic term student - talib - is asking or demanding (the knowledge, in that case).

Al-Bahlani's close student friend, Ahmed bin Said bin Halfan al-Khalili, later became a prominent Islamic scholar. In the biography of al-Bahlani, it is mentioned that his friend predicted the fate of the great poet, when he, as a teenager, told al-Bahlani of a strange dream in which a colony of white ants crawled out of his mouth. "God will open before you the gateway to the world of poetry!" concluded Ahmed bin Said bin Halfan (Al-Madani 2018). Indeed, before he reaching his second decade al-Bahlani had begun to write. Al-He was later to 
write about and mention the figure of his friend in his most famous poem $\mathrm{Al}$ Nuniyya (1914).

When al-Bahlani was twenty years old, he left Oman and went to Zanzibar with his father who was appointed as a judge there in the time of governance of local sultan Barghash bin Said. The Sultan, who ruled from 1870 to 1888 , established liberal progressive reforms, new infrastructure, including construction of roads, the new city of Stone Town, water infrastructure development and telegraph communication. Furthermore, the most progressive act of his rule was in the sphere of human rights, when he abandoned the slave trade and closed down the slave markets ${ }^{3}$. Later, al-Bahlani, being a very educated person, became a judge too, and was appointed advisor to the next sultan, Hamad bin Thuwaini bin Said (reign of 1893-1896), whom he admired and repeatedly praised in his poems.

When Hamoud bin Mohammad bin Said (1896-1902) was appointed Sultan of Zanzibar, al-Bahlani accompanied him on political trips to East Africa, and on his return wrote a book entitled The dazzling brilliance of the journey of our master the great Sultan Hamoud bin Mohammad bin Said to East African countries (al-lawaami' al-barqiyya fii rihlat mawlaanaa as-sultaan al-mu'azhzham hammuud ben muhammad ben sa'iid bil aqtaar al-ifriiqiyya assharqiyya). When, in 1902, the reins passed to Hamoud's son, Sultan Ali bin Hamoud bin Mohammad (in power until 1911), al-Bahlani left the civil service and decided to devote his life completely to civil society-building and educational projects.

Undoubtedly, the positive changes in Zanzibar and the mood of a general upsurge motivated society to attempt to carry out reforms in the host territory of the former dominion, i.e. on mainland Asian Oman. Al-Bahlani's political activity and these conditions of transformation encouraged al-him to work more closely with journalism, and later he was to become the mouthpiece of the political movement of the Ibadites (Al Faisal Magazine, 2016).

\section{THE EVE OF OMANI JOURNALISM}

In 1911 al-Bahlani launched the first edition of the four-page Arabic language newspaper Al-Najah ("Success") in Zanzibar. That was a crucial event as it was the beginning of Oman journalism overall (Al Moheet 2020). The weekly newspaper was founded by al-Bahlani and his peers - poet Ahmed bin Hamoud al-Harthi, Sheikh Ahmed bin Seif alHarudi. The newspaper's motto combined two expressions reflecting the intention to persist and to change the un- fair order of things: a phrase from 88th ayah of the 11th Surah Hood - "I just want to change/fix what is in my power" (In uriidu illa al-islaah ma stat'u) (Quran 2020), and the common saying "Patient and hardwork know success" (kullu ma sabara ala al-'amal adraka an-nadjaah).

The newspaper covered topics such as social issues, Arab world problems, world politics and literature questions. Soon the newspaper turned more to the political dimension, especially when 
Sheikh Nasser bin Suleiman al-Lyamki was appointed editor. He openly criticized the policy of Great Britain in the regions of the Middle East and Africa, calling it a "divide and conquer" approach (Atheer 2015). The topics raised in the newspaper attracted the attention of the British governors in the region. It was a time when the British were relaunching their activities in the Persian Gulf and East Africa. In 1902 Robert Cecil, Marquis of Salisbury was followed as Prime Minister by Arthur James Bal- four, who incidentally had already earned the nickname "Bloody Balfour" for suppressing Irish resistance. The newspaper was closed in 1914 and chief editor al-Lyamki was exiled to India. Later al-Lyamki and other editors who worked at Al-Najah launched and developed their own Omani periodicals such as the Al-Kifah (1928), Al-Falak (1929) and Al-Nahda (1951). All of them were influenced by the first experience of al-Bahlani's periodical and followed his progressive spirit.

\section{IBADISM IN THE LIFE OF AL-BAHLANI}

Al-Bahlani lived most of his life in Zanzibar and gained fame mainly as a poet, but his entire creative legacy appealed to Omanis, citizens of his homeland. He worked hard to promote unity and solidarity, to present a political and social solution to the problems of his time, through an attempt to implement the traditions of Ibadism and realize his dream to recreate a united imamate throughout the separated lands of Oman.

Since 1859 Zanzibar was already de jure separated from Oman due to local dynastic conflicts and British arbitration; the state in the inland territories and the sultanate on the coast (Muscat, Matrah) co-existed with their different developments. Some of the territories were dependent on Britain and served its interests. Moreover, the situation in interior Oman in the first decades of the twentieth century was complicated by high taxes imposed by the coastal territories Sultan on products sold interior farmers, which caused hunger and strangulation not only of the imamate's economy but also of the second part of the country. The consequences of economic stagnation and political disintegration were terrible, with Arab historians writing that Indian merchants who had lived and traded for centuries in Oman were forced to leave their businesses Ghobash 1998:286).

Many people in the Arab world supported the idea of cooperation with the British on account of political and economic benefit or, in the case of promoters of Arabic nationalism, as a factor in the survival and development of united Arab nations though practically it resulted in divided Arab nations. Despite this, alBahlani considered that the only solution for his country in all spheres could be found in following the movement of Ibadism as a political ideology. He saw that the only way to solve the economic needs of Omani society was to focus attention on following Islamic traditions, especially Sharia, in understanding Ibadism and achieving the revival of a united Oman'. 
Thus, al-Bahlani followed Islamic values and promoted religious ideas; however, his active participation in political life meant that his views embodied both open and society-oriented aspects. So, besides being an advisor to the five Sultans of Zanzibar, he maintained relationships and conducted intellectual correspondence with many prominent people of the region, including leaders of reformist movements in Egypt; the Ibadi leader of the reformist movement in Algeria Mohammed bin Youssef Attafeyish, who was a zealot of Islam, an implacable fighter against colonialism, and the founder of eight Arabic-language periodicals; Sheikh Sulayman Pasha alBaruni, a prominent figure in the history of Libya, who was repeatedly arrested by the Ottoman authorities for trying to restore the Ibadite imamate in the Nafusa Mountains region; Kassem Said alShamakhi, an outstanding Tunisian thinker living in Egypt; al-Mustafa Riyad Pasha, three times Prime Minister of Egypt; and others. Undoubtedly, these ideas more and more absorbed his religious notion and moved him to promote them for state life and society.
Thus, al-Bahlani followed Islamic values and promoted religious ideas; however, his active participation in political life meant that his views embodied both open and society-oriented aspects. So, besides being an advisor to the five Sultans of Zanzibar, he maintained relationships and conducted intellectual correspondence with many prominent people of the region, including leaders of reformist movements in Egypt; the Ibadi leader of the reformist movement in Algeria Mohammed bin Youssef Attafeyish, who was a zealot of Islam, an implacable fighter against colonialism, and the founder of eight Arabic-language periodicals; Sheikh Sulayman Pasha alBaruni, a prominent figure in the history of Libya, who was repeatedly arrested by the Ottoman authorities for trying to restore the Ibadite imamate in the Nafusa Mountains region; Kassem Said alShamakhi, an outstanding Tunisian thinker living in Egypt; al-Mustafa Riyad Pasha, three times Prime Minister of Egypt; and others. Undoubtedly, these ideas more and more absorbed his religious notion and moved him to promote them for state life and society.

\section{AESTHETIC FEATURES OF AL-BAHLYANI'S IDEOLOGICAL POETRY}

Soon, al-Bahlani decided to leave Zanzibar and return to his homeland, but in 1920 he died. Shortly before his passing, the leader of the interior region of Oman, forming the imamate, imam Salim bin Rashid al-Kharussi was killed by a mercenary from the coastal region hostile to the imamate (Ghobash 1998:291). However, the poet managed to send the imam the most famous of his works, the poem "Feat of the Sword and Faith" ("al-fath wal-rydwaan fis sayf wal imaan"), consisting of 400 verses, so that he could distribute it among the sheikhs of the Omani tribes to raise their spirits at that difficult time. Al-Bahlani was the author of many a qasida, which is a solid poetic form in the Middle East, with a large volume of 
more than 200 stanzas and a given composition that gravitates towards folklore. This famous qasida was named Al-Nuniyya - each verse ending with the nun letter of the Arabic alphabet, serving as a rhyme that passes through the path of the whole work. It should be noted that $A l$ Nuniyya is not an invention of al-Bahlani himself, but a subgenre of Arabic verbal creativity, and is also found in other authors' works. The greatest poets of Andalusia in the 11th century were famous for this technique, among them Ibn Zaydun, the Damascene theologian of the early 14th century Ibn Qayyim al-Jawziyya, the Andalusian imam al-Kahtani (died in 1001) and the poet of the early 11th century Abu al-Fath al-Busti.

Al-Nuniyya and the heritage of alBahlani as a whole are considered very influential for the unity of the revival of the nation and have had a great impact on Omani identity. There is evidence of its supreme value. Firstly, the collection of al-Bahlani's ten qasidas became the first Omani edition printed by a modern printing house in 1914, in Cairo, in one of the printing houses of al-Baruni mentioned above. Secondly, the work of alBahlani became part of the educational programme for all subsequent generations of Omanis. Due to this, Al-Nuniyya was accordingly included in the library of Omani families, following the Quran and the Young Guidance (Talqiin al-subyaan) by Nur ad-Din al-Salmi, who was included on the UNESCO honorary list before al-Bahlani. Al-Bahlani's collected works have been reprinted in 1957, 1980 and in 1986, and besides these, individual works have been created, such as handwritten copies by calligraphers, and audio recordings by famous readers when that became technically possible.

Moreover, al-Bahlani was a founder of the Omani School of Poetry, which recognized and has formed a generation of writers of modern Omani poetry. The school was named by researchers "the poetry of internal exile", with its classical Quranic Arabic language. It was famous for an appeal to the country's history, moods of rebellion and non-conformism, topics of separation from the homeland, death, departure, loss, fate, and attempts to comprehend the human being (Al Faisal Magazine, 2016). Many of al-Bahlani's followers were his contemporaries in other Gulf states, in particular, Muhammad Abdullah bin Athimin in Qatar (d. in 1944), who presented his poetic glorification of the Saudi Arabian king Abdel Aziz Al Saud in the same rhythm and with the same rhyme as alBahlani's Al-Nuniyya.

Even one of the characters in the novel Celestial Bodies by Omani writer Jokha al-Harthi ${ }^{5}$, makes children learn Al-Nuniyya by heart and "with tears in his eyes, he then listened to their recitation" (alHarthi, 2019: 193). And there is the hero, who was forced to emigrate to Egypt after the civil conflict of 1954-1959 caused by the attempt of Imam Ghalib Alhinai to protect the imamate from Sultan Said bin Taimur - who applied all his strength to publish and disseminate the works of al-Bahlani in Cairo.

Al-Bahlani's poetry embraces various poetic genres traditional in Arabic oral heritage - al-madih (an ode to glory), alrithaa (epitaph), al-ghazal (love lyrics), 
al-istinhad (civic lyrics), al-munasaha (didactics, instructions). Nevertheless, his verses (al-beit in Arabic as a single metrical line) with religious content are estimated at almost two-thirds of everything he created (Al-Mahrouqi 2001). These are works such as the Wahhabi Faith (al-'aqidah al-wahhabiyyah), The Book of Questions (kitaab al-suaalaat), Muhammad: the Beginning (al-naashiat al-muhammadiyya) (sung at the celebrations of the Prophet's (al-Mawloudiyah) birthday celebrations in Zanzibar, in the Libyan valley of Mizab, on the island of Djerba (Tunisia) and other centers of Ibadism), The Gift of the Most Merciful (al-nafas alrahmaani), Dazzling Light (al-lawaami' albarqiyyah), and the Qasida al-Wadi alMukaddas (Holy Valley) that contains a record 1,500 verses. Al-Bahlani's collected works has about 900 pages.
Al-Bahlani's religious verses are conditionally divided into those where the Prophet is praised, and those which are a prayer to God. Nevertheless, all were created within the course of Ibadism and integrated as an active political component. In prayers to the Almighty the following obligatory parts are distinguished: 1. Introduction; 2. Confession of sins; 3. A request to God to answer the prayer; 4. Ascension of gratitude to God; 5. Prayer to protect oneself from enemies. 6. Praying to God to make him an imam. We have to note that part two is not at all formal for al-Bahlani as an Ibadite.

The poet's devotion to the confession of his own sins and his repentance sometimes takes up to 90 lines. All this testifies to al-Bahlani's unquenchable desire to fight against external aggression, and for social justice and spiritual practice.

I repented to you from sins I have committed in secret

I repented to you from sins I have committed in public

And from sin which break up the age

And from sin which cause poverty

And from sin whose outcome is to touch Hell

I repented to you from the notions of committing sins

And everything which has been forbidden by the God pen

And everything I did again after repentance

And from what I profaned of the sacred

And from every secret sin: large or small.

(Above and further we give the text in the English translation of al-Mahrouqi (Al-Mahrouqi 2001: 94)

Among al-Bahlani's other significant works of a purely civic orientation are al-Maqsura with 393 verses, My Homeland (Watany), where each of the 250 lines (beits) ends in the letter mim, the socalled Al-Mimiyya. The latter work alBahlani addressed to Sheikh Issa bin
Saleh al-Harthi, the emir of the eastern Oman tribes, in admiration for his support in favour of the imamate and imam Salim bin Rashid al-Kharussi.

In addition to following the canon of classical Arabic language where the Omani dialect is the closest to the classical (Zarytovskaya 2011), Arab scholars who studied al-Bahlani's poems indicate that nothing has influenced the style of 
his works more than the Holy Quran, not only in content but also in form (AlMahrouqi 2001: 93). Among the artistic features of al-Bahlani's heritage, we single out the repetition of phrases and the beginnings of phrases. Moreover, as follows from the passage, wherein a strictly fixed syntactic order of words is mentioned, such as: 1) I repented - 4 times; 2) in the sin that - 3 times; 3) and all that I - 2 times; 4) and - 2 times, a verse can consist exclusively of lines beginning with overlapping repetitions. Schematically, they can be depicted, according to the assigned ordinal numbers, as 1-1-22-2-1-1-3-3-4-4.

The linguistic subtleties of al-Bahlani's poetry are also presented in the format that continues the Arabic verbal tradition of luzumiyat (from Arabic: luzuum - obligatoriness), where the author undertakes to start each new line of the poetic work in alphabetical order of the initial letter. So, the first line begins with the first letter of the alphabet alif, the second - with $b a$, etc. At the same time, the language puzzle (for the compiler, since these verses require deep meaning and aesthetic beauty as well as a balance between poetic technique and the clear presentation of ideology) is complicated by the fact that the initial letters of each line must appear in the line several times, thereby achieving a special phonetic effect of enhancing the meaning of what was said and creating sensitivity. Let's give an example of a line with the initial letter ayn (sounds like deep glottal bow), which we mark in transcription with ${ }^{*}$, as there is no any similar analogue sound or letter in European languages:

$$
\begin{aligned}
& \text { *aliil wa maa bii *illa ghayr anti } \\
& \text { suluukii hubb al-mustafaa saara *illatii } \\
& \text { Ill, my illness is following al-Mustafa } \\
& \text { My way of love al-Mustafa caused my illness }
\end{aligned}
$$

(Al-Bahlani 1986: 287)

Here, al-Bahlani uses the semiotic possibilities of the language - the use of the same word, its phonetic shell, in all possible values, and this is subject to the location of the lexical unit in different values being as close to each other as possible. In addition, he implements "roll calls" at the levels of phonetics (sound assonance), vocabulary (repeating a word), grammar (constructing phrases according to a given pattern) and syntax (duplicating sentences).

For example, the phrase in the name of God in one of the works is repeated 130 times, or a line beginning with To the Almighty is repeated three times in a row (AlMahrouqi 2001: 102). Also, the word khaal is used in all its four meanings throughout only two lines - as the past, as a desert (twice), as a mountain and as a mole:

ma*aahid ashdgaanii takhuulak al-khaal wama*ra*ii al-mahaa bil khaal laa aqfaz al-khaal wuquufan bisafah al-khaal asfah *ibra ukafkifuha *azmii wa awakkifuhaa al-khaal 
Places of my beloved, the past has destroyed you

I hope the places where the gazelles graze in the desert will never be without greenery.

Standing on the top of the mountain I pour out tears

My determination held them back and the beauty spot makes them flow.

(Al-Mahrouqi 2001: 102)

The author introduces duplication and takes not a single word but a whole wordbuilding construction, i.e. one-root lexical units of the same root, which are concen- trated as tightly as possible throughout the text so that the listener feels the folded assonance.

taqaddastu yaa qadduus *an djins *illa wa *an hadd ma*luul

(I have highlighted the root q-d-s and the root * -1-1 by underlining the words)

O Holy One, your hallowed by not being affected by any case or by the border of what its caused or by the border of what is caused or delineation of nature

(Al-Mahrouqi 2001: 103)

In the main the artistic features of alBahlani's texts, on the one hand testify to his high level of proficiency with the word and how he masters it - that deserves attention both from a linguistic point of view and from an aesthetic one. On the other hand, these features indicate that the poet was inspired by religious texts and created works that were not to be read to oneself but were for expressive and public recitation. The abovementioned techniques help in promoting his patriotic, political, and civil content works and result in them having a strong emotional impact on the public. It is exactly this form of creativity, following the meaningful religious canon and at the same time using these effective techniques as a call to social action, which, in our opinion, enable al-Bahlani's work to reach its unequivocal peak in the Ibadite environment ${ }^{6}$.

\section{CONCLUSION}

The understanding of the history, policy, theology, or literature of Oman is impossible without the research into the impact of al-Bahlani, a central figure in the contemporary history and culture of Oman. His writings, empowered by the spirit of transformation, have significantly influenced the modern identity of Omani society. The ideological ideas of al-Bahlani created the pillars and strengthened the unification of separated Omani society and, further, became a strong background for active state building and development. The introduction of his ideas strengthened democratic values and social welfare in the country. That is the reason why this research focuses on historical and religious contexts in the analysis of al-Bahlani's poetry.

The educational activity of al-Bahlani laid the basis for the development of Omani journalism and educated an entire generation of editors and journalists of national periodicals and journals. His civil lyrics played an important historical role in strengthening public admin- 
istration, in resistance to the secular sultan's power and the colonial policy of the Europeans.

Besides al-Bahlani's literary masterpieces that penetrated all levels of the language, he is recognized as a master of the word and his works as literary classics of the Gulf countries. He is acknowledged as a creator of text who brought to perfection such techniques of Arabic poetry as the rhyme for a closed syllable ending in the same consonant, the so-called luzumiyat, repetition, and the roll call at all levels of language, from phonetics to syntax and semantics.

Surely, the central place in al-Bahlani's educational and intellectual activity was the promotion of Ibadism through the advocacy of the rule of law, the acceptance of resistance to a governance that did not follow Sharia norms, strict relation towards oneself in following religious norms, and a non-possessive, human relation towards an enemy. That allowed its influence - considering all aspects of the unique, almost closed

\section{References}

Al Faisal Magazine. 2016. Samaa' Issa. Contemporary Omani poetry. Retrieved 2020, from https:// www.alfaisalmag.com/?p=2858

Al Moheet. 2020. Information about Al-Najah newspaper. Retrieved 07 2020, from https://almoheet. /النجاح-صحيفة_عن-معلومات/_Abu

Al-Bahlani, A. M. 1986. Abu Muslim Poems Collection.Amman: Salih Bin Issa Al-Harthi.

Al-Harthi, J. 2019. Women of the Moon. Beirut: Dar Al-Adab.

Al-Madani, A. 2018. Omani Poet Al-Bahlani "Poet of Scholars and Society". Retrieved from https:// www.okaz.com.sa/culture/na/1671328

Al-Mahrouqi, M. 2001. Religions discourse in the poetry of Abu Muslim al-Bahlani. Journal of African cultural studies, Vol 14 № 1 June, 89-106. borders of Oman, and its religious and cultural phenomena in practice - to make itself felt on the historical development of the Sultanate, on its social activity, culture and intellectual processes.

Meanwhile, we cannot neglect that Ibadism created an exclusive platform and initiated an atmosphere that enabled the flourishing of civil poetry and the promotion of emotional ideological influence. It was, indeed, precisely these which created strength in the society, which resulted in the active political and civic positions held by the Ibadists and which followed the tension in society against governance.

Unfortunately, due to internal political developments and the consequent late openness of the state towards cultural masterpieces and activities, many prominent figures such as al-Bahlani have been left unknown outside Oman. This lowers our understanding of the culture, lifestyle, society, and public affairs of this Gulf State.

Al-Rawas, I. 2000. Oman in early Islamic history. Reading: Gamet publishing Ltd.

Al-Shahri, B. N. 2005. Oman Press: History of development, typological and genre features. Thesis. Moscow: RUDN.

Atheer. 2015. https://www.atheer.om/archives/1119. Retrieved from Al-Lamki, Sheikh Muhammad bin Nasser - a pioneer of the history of the Omani press.

Atik, H., \& Shaaban, S. 2015. Political Thought in Ibadism. (الفكر السياسي في الإباضية). Thesis. Algeria: University of Buira.

Babaahmed, I. 2019. Nasser bin Salem Al-Bahlani "Abu Muslim". Retrieved 07 08, 2020, from https://www.omandaily.om/?p=697809

Ghobash, H. O. 1998. Oman, Islamic democracy. 
Imamate traditions and marginal political history. Beirut: New Dar.

Hoffman, V. J. 2015. Ibādism: History, Doctrines, and Recent Scholarship. Religion Compass, 9, 297-307.

Husa, A. A. 2020. Ibadism and the Geopolitics: Oman and Manifesto. Retrieved from https://hmanyah. com/3421/

Ignatenko. 2000, No 3. Introduction Article (in Arabic). In Y. Al-Janavni, Book of Establishment. A summary of the foundations of faith and law (pp. 128-135).

Ignatenko, A. 2009. Islam in the modern world. The Divine and the Human in Islam. Islamic Studies, № 1.

Nizwa. 1996. Abu-Muslim Al-Bahlani Omani Poetry. Retrieved from http://www.nizwa.com/ /ا_العماني_الثعر -ر ائد_البهلاني_مسلم-ابو

Oman Observer. 2019. Abu Muslim al Bahlani among global influential figures. UNESCO. Retrieved from https://www.omanobserver.om/abu-muslim-al-bahlani-among-global-influential-figuresunesco/

\section{Endnotes}

1 The most important theorist of Ibadism was Jabir bin Zeid (died in 716). He was succeeded by Abdullah ibn Ibad at-Tamimi, with his name, ibn Ibad, becoming the eponym for the Ibadi movement.

2 In 1957, during the Oman War, one of the battles took place in al-Jebel al-Akhdar valley, where the rebels - followers of one of the Ibadite Imams - were based. Afterwards the battle became known as the Jebel Akhdar War.

3 Despite the law, the slave trade continued to exist for a long time, until its end was decreed on September 25, 1926, by the Geneva Convention on Slavery.

4 The first society of Arab nationalists "Young Arab Society" ("Al-Fatat") was created in 1909 in Paris. It was the movement of Arab uprisings on the Arabian Peninsula against the Ottoman Empire. The peak of the nationalist movement was reached during the reign of President Gamal Abdel Nasser in Egypt (1956-1970) and
Oman Observer. 2019. Omani poet among world's influential figures. Retrieved 07 08, 2020, from https://www.omanobserver.om/omani-poetamong-worlds-influential-figures/\&hl=ru\&gl=r u\&strip $=1 \& v w s r c=0$

Quran. 2020. Islam Global. Retrieved from Quran Translation: https://islam.global/verouchenie/ koran/sura-11-khud-khud-/

Senchenko, I. 2020. Sultanate of Oman. Legends, Tales, and Facts of History. San-Petersburg: Aletheia.

The Booker Prizes. 2019. The Winner 2019. Retrieved from The Booker Prizes: https://thebookerprizes.com/international/2019

Wilkinson, J. 1986. The Imamate Tradition of Oman. UK: Cambridge University Press.

Wilkinson, J. C. 2010. Ibâdism: Origins and Early Development in Oman. Oxford: Oxford University Press.

Zarytovskaya, V. 2011. Omani dialect of the Arabic language: historical and linguistic description. Collection of materials of the scientific and methodological seminar: The linguistic aspect of integration and self-identification in the modern world, 28-30.

connected with ideologists such as Amin alRihani, Constantin Zureik, Michel Aflak. Finally, some of the ideas were implemented for short periods with the uniting of Egypt and Syria in 1958, of Libya, Egypt and Syria in 1972, and of Tunisia and Libya in 1974, the latter, however, existing only on paper for a very short time.

5 The novel Celestial Bodies (in the original Sayyidaat al-Qamar) written by Jokha al-Hharthi, won the 2019 Man Booker International Prize (The Booker Prizes, 2019).

6 There is additional evidence that Ibadism made an impact on religious and legal movements and created conditions for the development of civil poetry in Algeria. The author of the text of the Algerian anthem was also an Ibadite representative. In Algeria the Ibadis are represented by an insignificant minority, coming from the aforementioned Mizab - the "poet of the Algerian revolution" Moufdi Zakaria (1908-1977). 